\title{
Analysis of Expression and Single Nucleotide Polymorphisms of INHA Gene Associated with Reproductive Traits in Chickens
}

\author{
Zhifu Cui, Lingbin Liu $\mathbb{D}$, Xiaoling Zhao, Jinshan Ran, Yan Wang $\mathbb{D}$, \\ Huadong Yin, Diyan Li $\mathbb{D}$, and Qing Zhu $\mathbb{D}$
}

Farm Animal Genetic Resources Exploration and Innovation Key Laboratory of Sichuan Province, Sichuan Agricultural University, Chengdu 611130, China

Correspondence should be addressed to Qing Zhu; zhuqingsicau@163.com

Received 26 February 2019; Revised 2 July 2019; Accepted 15 July 2019; Published 8 August 2019

Academic Editor: Kui Li

Copyright (c) 2019 Zhifu Cui et al. This is an open access article distributed under the Creative Commons Attribution License, which permits unrestricted use, distribution, and reproduction in any medium, provided the original work is properly cited.

\begin{abstract}
Inhibin $\alpha(I N H A)$ is a candidate gene controlling ovulation in poultry. As the functional center of inhibin, INHA is a molecular marker associated with egg-laying performance. The objective of the current study was to analyze the expression differences of INHA in reproductive system and single nucleotide polymorphisms (SNPs) associations with reproductive traits in chickens. A total of 260 LuHua chickens (barred-feather chicken) were adopted. Twelve SNPs were detected in INHA gene. Among the exonic SNPs, three (g. 22177991A>G, g. 22178249G>C, and g. 22178414G>A) were missense mutations, resulting in the amino acid substitutions $\mathrm{Val} \longrightarrow \mathrm{Ala}, \mathrm{Ala} \longrightarrow \mathrm{Gly}$, and Ala $\longrightarrow$ Gly, respectively. Four SNPs in the 3' untranslated region of INHA were predicted to either disturb or create microRNA-target interactions. Five SNPs (g. 22176870T>C, g. 22177100T>C, g. 22177149T>C, g. 22177991A >G, and g. $22178975 \mathrm{G}>\mathrm{A})$ were significantly associated with the number of eggs at $300 \mathrm{~d}$ of age $(\mathrm{EN})(P<0.05)$. Birds carrying GA genotype exhibited more EN than those with AA genotype $(P<0.01)$. In addition, quantitative real-time PCR revealed that $I N H A$ is mainly expressed in follicles on d 300 in chickens. Firstly, INHA expression increased and then decreased. The highest INHA mRNA abundance was found in the fifth largest preovulatory follicle (F5) $(P<0.01)$. In the prehierarchical follicles, INHA mRNA expression increased dramatically in small yellow follicles (SYF) $(P<0.01)$. Western blotting analysis showed that the INHA protein expression profile in the follicle was similar to its mRNA counterpart with greater expression in F5 and SYF follicles and lowest expression in F1 follicles $(P<0.05)$. These results suggest that INHA is a potential candidate gene improving reproductive traits in chickens.
\end{abstract}

\section{Introduction}

Inhibin, a member of the transforming growth factor- $\beta$ (TGF- $\beta$ ) superfamily, plays an important role in modulating the reproductive axis and affects all reproductive events [1]. It is a gonadal glycoprotein hormone and is principally produced by the granulosa cells of ovarian follicles in females and by the sertoli cells of the testes in males [2]. Inhibin comprises multiple disulfide-linked dimers that shares a common $\alpha$-subunit (encoded by INHA gene) and differs in $\beta$-subunit; when the $\alpha$-subunit binds to $\beta \mathrm{A}$-subunit, inhibin $\mathrm{A}(\alpha \beta \mathrm{A})$ is formed, and when it binds to the $\beta \mathrm{B}$-subunit, inhibin $\mathrm{B}(\alpha \beta \mathrm{B})$ is formed. Both inhibin $\mathrm{A}$ and inhibin $\mathrm{B}$ have the ability to specifically suppress follicle-stimulating hormone (FSH) secretion in pituitary cells without affecting LH secretion [3-7]. In addition to its endocrine function, inhibin also shown to exert a variety of autocrine/paracrine in mammalian species. Many studies indicated a local role for these factors in modulating the growth of small follicles by regulating cell proliferation as well as expression of the inhibin subunits and gonadotropin receptors $[8,9]$.

Inhibin A is produced and secreted by the granulosa layer of the large pre-ovulatory follicle [10]. Immunizations against the INHA have resulted in increased ovulation in sheep, pigs, chickens, mice, and cows [11-15]. Therefore, the INHA is thought to be the functional center of inhibin and a potential candidate gene increasing the ovulation rate in poultry. In a murine knockout model, the INHA was found to play a tumor suppressive role in gonadal tissue after gonadectomy for the adrenal cortex, with $99 \%$ of INHA mice developing adrenocortical steroid-secreting carcinoma after gonadectomy $[16,17]$. Pathways involved in this effect include 
TABLE 1: Primer pairs used to screen the INHA gene polymorphism.

\begin{tabular}{|c|c|c|c|c|}
\hline Name & Sequences $\left(5^{\prime}-3^{\prime}\right)$ & Binding regions & Product size (bp) & $\operatorname{Tm}\left({ }^{\circ} \mathrm{C}\right)$ \\
\hline \multirow[t]{2}{*}{ P1 } & F-TATTCACGGCGAGCAGACA & \multirow[t]{2}{*}{ Exon 1} & \multirow[t]{2}{*}{562} & \multirow[t]{2}{*}{58.7} \\
\hline & R-CCTCAGCCCTCCCCATCT & & & \\
\hline \multirow{2}{*}{$\mathrm{P} 2$} & F-ATCCCACAGCCCCAAGACC & \multirow{2}{*}{ Exon 2} & \multirow{2}{*}{783} & \multirow{2}{*}{61.0} \\
\hline & R-GGCAGTAGTGGAAAACGAAGC & & & \\
\hline \multirow{2}{*}{ P3 } & F-CACTGGACCGTGTTTGACTTCG & \multirow{2}{*}{ Exon 2 Partial } & \multirow{2}{*}{589} & \multirow{2}{*}{51.5} \\
\hline & R-GGGATGGGCTCATCATCTGG & & & \\
\hline \multirow{2}{*}{$\mathrm{P} 4$} & F-CGGGAACTGTGCCGAAGG & \multirow{2}{*}{5 'UTR } & \multirow{2}{*}{749} & \multirow{2}{*}{58.7} \\
\hline & R-GCACCCCGCTGCATAACC & & & \\
\hline \multirow{2}{*}{ P5 } & F-TGTCCCAAACTCTGTCCAATG & \multirow{2}{*}{ 3'UTR } & \multirow{2}{*}{707} & \multirow{2}{*}{56.5} \\
\hline & R-CTCAAATGCTCCAGCACCC & & & \\
\hline
\end{tabular}

UTR: untranslated region.

the differentiation into granulosa cell-like cells with the expression of fetal or gonadal markers such as $L H R, F S H R$, and Cyp17a1 [18]. Recently, Li et al. found that INHA gene polymorphisms are significantly associated with the presence of follicular cysts in Large White sows [19]. In poultry, Chen et al. reported that the downregulation of INHA expression has an antagonistic effect on granulosa cell apoptosis [20]. Although many studies have shown that inhibin was a critical regulator of gonadal function, whether its expression level in the developing follicles or polymorphisms are associated with reproductive traits in chicken is still unknown.

In characterizing candidate genes, it is important to detect single nucleotide polymorphisms (SNPs) and analyze the associations between these SNPs and reproductive traits, together with assessing the role of gene expression. Therefore, the aim of this study was to characterize the role of the chicken INHA gene in determining chicken reproductive traits through SNP association and expression analyses.

\section{Materials and Methods}

2.1. Chicken Populations. The LuHua chicken (LH) is a local breed in Shandong province, P. R. China. It was included in the Key Poultry Breeds Requiring Protection in 2002. A total of 260 birds after hatching were raised in cages with the same housing conditions and diets. Their performances were measured in Poultry Breeding Farm of Sichuan Agricultural University (Yaan, China). Blood was collected, and genomic DNA was isolated using a standard phenol/chloroform method. The DNA purity and concentration were measured with a Nucleic Acid Protein Analyzer (Thermo Scientific, USA). Based on the original concentration, samples were diluted to the final concentration of $100 \mathrm{ng} / \mu \mathrm{L}$ with TrisEDTA buffer. All DNA samples were stored at $-20^{\circ} \mathrm{C}$ until use.

Six reproductive traits were measured: body weight at first egg (BWAFE), first egg weight (FEW), age at first egg (AFE), total egg number at 300 days of age $(\mathrm{EN})$, body weight at 300 days of age (BWTA), and egg weight at 300 days of age (EWTA). Traits determination was conducted in accordance with the Committee on Experimental Animal Management of Sichuan Agricultural University and carried out strictly according to the Regulations for the Administration of Affairs Concerning Experimental Animals of the State Council of China.

2.2. Sequencing of the INHA Gene. Primers for amplifying and sequencing the chicken INHA gene (Table 1) were designed with Primer Premier 5.0 software based on the complete DNA sequences of Gallus gallus INHA genes (ENSGALG00000054770). A DNA pool containing 100 ng DNA from each of the 60 least closely related chickens was constructed. PCR was carried out using a Gene Amp PCR System 9700 (Bio-Rad, Hercules, CA, USA) thermal cycler in a final volume of $25 \mu \mathrm{L}$ containing $8.6 \mu \mathrm{L}$ distilled $\mathrm{H}_{2} \mathrm{O}, 15 \mu \mathrm{L} 2 \times \mathrm{Taq}$ PCR Master Mix (including $\mathrm{Mg}^{2+}$, dNTPs, and Taq DNA polymerase; Beijing Tian Wei Biology Technique Corporation, Beijing, China), $0.3 \mu \mathrm{L}$ each primer $(10 \mathrm{nmol} / \mathrm{L})$, and 0.8 $\mu \mathrm{L}$ chicken genomic DNA template. PCR was performed with the following cycling conditions: denaturation at $94^{\circ} \mathrm{C}$ for 5 min; 35 cycles of $94^{\circ} \mathrm{C}$ for $30 \mathrm{~s}, 56-60^{\circ} \mathrm{Cfor} 35 \mathrm{~s}$ (Table 1 ), and $72^{\circ} \mathrm{C}$ for $40 \mathrm{~s}$, followed by a final extension at $72^{\circ} \mathrm{C}$ for $5 \mathrm{~min}$. PCR products were purified and sequenced via an ABI 377 DNA sequencer (Shanghai Sangon Biological Engineering Technology, Shanghai, China). All sequences were edited, assembled, and aligned with DNASTAR and Codon Code Aligner software (http://www.codoncode.com/aligner). SNPs were identified by the presence of multiple peaks at the same base by direct sequencing.

2.3. Genotypes Identification. Based on the DNA pools sequence results, single nucleotide polymorphisms were found in the amplification products of five primer pairs $\mathrm{P} 1$, P2, P3, P4, and P5. Further polymorphism genotyping was carried out one by one using DNA samples of 260 chickens. PCR and amplified products were carried out as describe as above.

2.4. Statistical Analyses. SAS 9.4 (Statistical Analysis Systems Institute Inc., Cary, NC, USA) was used to determine the relationship between genotypes and reproductive traits in chicken. The model used was: $Y_{i}=\mu+G_{i}+e_{i}$, where $Y_{i}$ is a reproductive trait measured in the chickens, $\mu$ is the 
population mean of the trait, $G_{i}$ is a fixed effect genotype, and $e_{i}$ is the residual error. Significance was determined using Duncan's multiple range tests. Pearson's chi-square test was used to assess the Hardy-Weinberg equilibrium of the four SNPs discovered in the present study. The linkage disequilibrium (LD), $D^{\prime}$ and $r^{2}$ values of the SNPs were estimated by Haploview [21]. The polymorphism information content (PIC) was determined following a previous method [22]. In addition, haplotypes were constructed using the PHASE program v. 2.0. Haplotypes were analyzed using the model for the single marker association test by considering birds with 0,1 , or 2 copies of the haplotype in question. The PROC REG procedure of SAS (version 9.4, SAS Institute Inc.) was used to perform the analysis. Values were significant at $P$ $<0.05$.

2.5. Expression Abundances of INHA mRNA. To determine the reproductive system tissue-specific expression patterns of INHA mRNA, total RNA was extracted from the tissues of five chickens at 25 weeks, including the fallopian tubes (infundibulum, isthmus, and uterus), hierarchical follicles (F1, F2, F3, F4, and F5), and prehierarchical follicles [small white follicles (SWF), small yellow follicles (SYF), and large white follicles (LWF)], using TRIzol reagent (TakaRa Biotech Co. Ltd., Dalian, China) and was dissolved in RNasefree $\mathrm{H}_{2} \mathrm{O}$ (Tiangen Biotech Co., Ltd, Beijing, China). The integrity of the RNA was evaluated via electrophoresis on $1 \%$ agarose gels, and the concentration and purity were analyzed with a NanoDrop 2000 by determining the absorbance ratio of 260/280 $\mathrm{nm}$ (Thermo Scientific, Waltham, MA, USA). The cDNA was synthesized by reverse-transcription PCR using $1 \mu \mathrm{g}$ total RNA, $2 \mu \mathrm{L} 5 \times$ RT buffer, $0.5 \mu \mathrm{L}$ RT enzyme mix, $0.5 \mu \mathrm{L}$ primer mix, and $6 \mu \mathrm{L}$ nucleasefree water (Toyobo Life Science Department, Shanghai, China). The reverse transcription reaction was maintained at $37^{\circ} \mathrm{C}$ for $15 \mathrm{~min}$, followed by incubation at $98^{\circ} \mathrm{C}$ for $5 \mathrm{~min}$. The cDNA samples were stored at $-20^{\circ} \mathrm{C}$. Genespecific primers (Fw: 5'-ACTACTGCCACGGGAACTGT3', Rv: 5'-GGAGTAGCCACCATCAGAGG-3') for qRT-PCR were designed using Primer 5 software according to the coding sequence of the chicken INHA gene (GenBank accession no. NM_001031257). qRT-PCR was conducted via a CFX96 Real-time System (Bio-Rad, Hercules, CA, USA) with the following conditions: $98^{\circ} \mathrm{C}$ for $2 \mathrm{~min} ; 39$ cycles of $98^{\circ} \mathrm{C}$ for $5 \mathrm{~s}$ and $55.7^{\circ} \mathrm{C}$ for $10 \mathrm{~s}$; followed by a final extension at $95^{\circ} \mathrm{C}$ for $10 \mathrm{~s}$. Each PCR reaction contained $5 \mu \mathrm{L}$ Ssofast Evagreen supermix (Bio- Rad, Hercules, CA, USA), $1 \mu \mathrm{L}$ of cDNA (50 $\mathrm{ng} / \mu \mathrm{L}), 0.8 \mu \mathrm{L}$ each primer $(10 \mu \mathrm{M})$, and $2.4 \mu \mathrm{L} \mathrm{ddH}_{2} \mathrm{O}$ to a final reaction volume of $10 \mu \mathrm{L}$. All samples were triplicated. The housekeeping gene $\beta$-actin (GenBank accession no. AF047874; Fw: 5'-GAGAAATTGTGCGTGACATCA-3', Rv: 5'-CCTGAACCTCTCATTGCCA-3') was used for normalization of target gene expression [23]. The relative gene expression levels of INHA were calculated using the comparative $2^{-\Delta \Delta \mathrm{CT}}$ method [24], where $\Delta \mathrm{Ct}=\mathrm{Ct}$ target gene $-\mathrm{Ct}$ housekeeping gene. Differences in INHA mRNA expression were examined by one-way analysis of variance (ANOVA). Data are presented as the mean \pm standard error means (SEM), and significances were determined at $P<0.05$.
2.6. Expression Abundances of INHA Protein. INHA protein expression levels in different follicles were detected by Western Blotting. Total protein was extracted from the tissues of five chickens at 25 weeks, including the hierarchical follicles (F1, F2, F3, F4, and F5) and prehierarchical follicles (SWF, SYF, and LWF) using a Protein Extraction Kit (BestBio Biotech Co. Ltd., Shanghai, China). The concentration and purity of the protein samples were determined using a BCA Protein Assay Kit (BestBio Biotech Co. Ltd., Shanghai, China); standard curves were drawn to calculate the protein concentration. Samples were triplicated. The $\beta$-actin protein was used as a reference. A total of $25 \mu \mathrm{g}$ protein was resolved by sodium dodecyl sulfate-polyacrylamide gel electrophoresis (SDS-PAGE) and transferred to polyvinylidene fluoride (PVDF) membranes. After blocking with $5 \%$ non-fat milk in 1×Tris-buffered saline with Tween (TBST) buffer for $2 \mathrm{~h}$ at room temperature, membranes were incubated with rabbit anti-chicken INHA monoclonal antibody (Abcam, Cambridge, UK; 1:1000) and rabbit anti-chicken $\beta$-actin monoclonal antibody (Abcam, Cambridge, UK; 1:1000) overnight at $4^{\circ} \mathrm{C}$. Blots were then washed in $1 \times$ TBST buffer and probed with goat anti-rabbit horseradish peroxidase (HRP)conjugated IgG secondary antibody (diluted 1:2000 in $1 \times$ TBST; Abcam, Cambridge, UK) for $1 \mathrm{~h}$ at room temperature. Binding was visualized with enhanced chemiluminescence (ECL) reagent (Beyotime Institute of Biotechnology, Jiangsu, China) using a ChemiDoc XRS instrument (Bio-Rad, Hercules, CA, USA). Quantity One Software (Bio-Rad, Hercules, CA, USA) was used for densitometric analysis [25].

\section{Results}

3.1. Allele and Genotype Frequencies of Chicken INHA Gene SNPS. All exons and part of the untranslated region (UTR) of the chicken INHA gene were amplified and sequenced. A total of 12 SNPs were detected (Figure 1). Among them, one was located in the promoter region, three were in exon 1 , three were in exon 2, and five were in the 3' UTR (Table 2). Among the exonic SNPs, g. 22177991 A>G, g. 22178249 G>C, and g. $22178414 \mathrm{G}>\mathrm{A}$ were missense mutations, which resulted in the amino acid substitutions Val $\longrightarrow$ Ala, Ala $\longrightarrow$ Gly, and $\mathrm{Ala} \longrightarrow \mathrm{Gly}$, respectively. SNPs in the 3' UTR were predicted to either disturb or create microRNA- (miRNA-) target interactions. Ten miRNA interactions weakened and four miRNA interactions strengthened (Table 3).

The genotype and allele frequencies and related genetic information for the 12 SNPs in the chicken INHA gene are summarized in Table 4. For all SNPs, their genotype and allele frequencies were above $5 \%$, which indicated that it was appropriate to conduct INHA gene analysis. For SNP1, the CT genotype frequency (0.6121) was higher than those of CC (0.3103) and TT (0.0776), and the allele frequency of $\mathrm{C}(0.61635)$ was higher than that of $\mathrm{T}(0.38365)$. The heterozygous genotype frequency was higher than the homozygous genotype frequencies for all 12 SNPs. The original allele frequency was higher than the mutant allele frequency for SNP1, SNP2, SNP3, SNP4, SNP7, SNP8, and SNP9, respectively, while the original allele frequency was lower than the mutant allele frequency for SNP5, SNP6, 

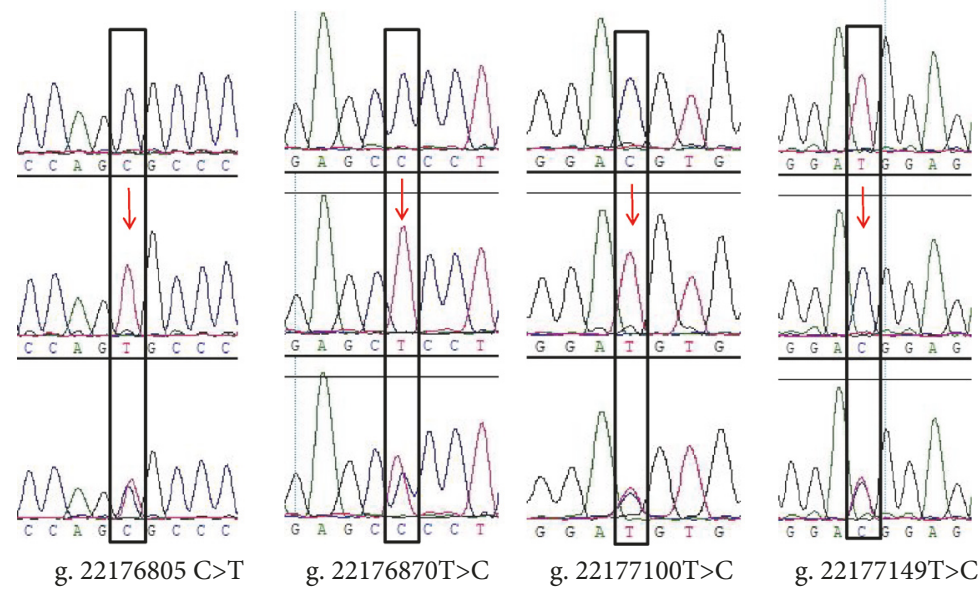

g. $22176870 \mathrm{~T}>\mathrm{C}$

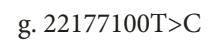

g. $22177149 \mathrm{~T}>\mathrm{C}$
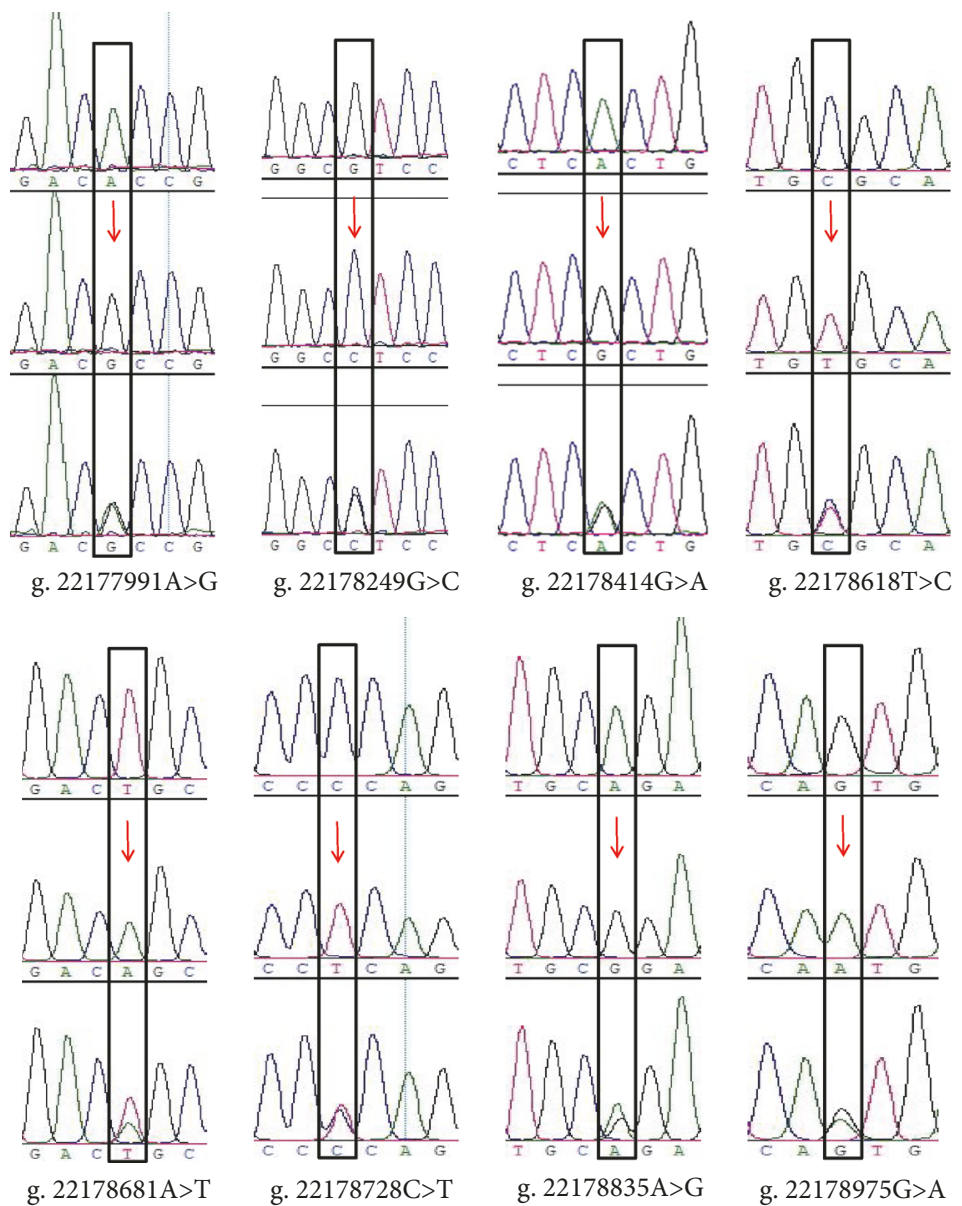

g. $22178728 \mathrm{C}>\mathrm{T}$
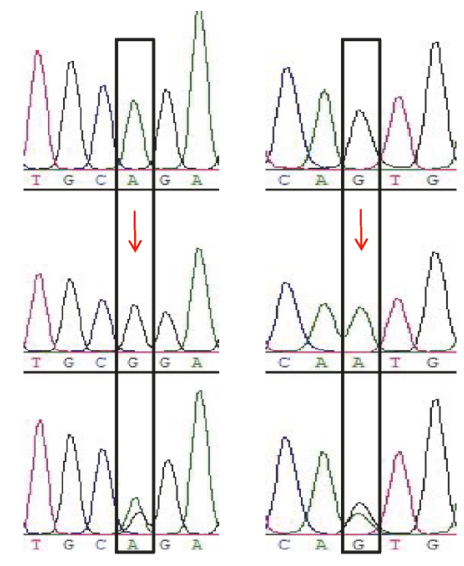

FIGURE 1: SNP sequence map of INHA gene. Red arrow indicates mutation site.

SNP10, SNP11, and SNP12. The PIC test results indicated that all SNPs could be considered intermediate polymorphisms, making them good genetic markers. All SNPs except SNP1 were in Hardy-Weinberg equilibrium $(P>0.05)$.

3.2. Relationships between Genotypes and Reproductive Traits. The results of the association analyses showed that g. $22176870 \mathrm{~T}>\mathrm{C}$, g. $22177100 \mathrm{~T}>\mathrm{C}$, g. $22177149 \mathrm{~T}>\mathrm{C}$, g. $22177991 \mathrm{~A}>\mathrm{G}$, and g. $22178975 \mathrm{G}>\mathrm{A}$ were significantly associated with EN $(P<0.05$, Table 5$)$. No significant associations were found between other SNPs and the reproductive traits. Therefore, subsequent genotype association analyses were performed for g. $22176870 \mathrm{~T}>\mathrm{C}$, g. $22177100 \mathrm{~T}>\mathrm{C}$, g. $22177149 \mathrm{~T}>\mathrm{C}$, g. 22177991A $>\mathrm{G}$, and g. $22178975 \mathrm{G}>\mathrm{A}$ (Table 6). The results showed that genotypes at the g. $22176870 \mathrm{~T}>\mathrm{C}$, g. $22177100 \mathrm{~T}>\mathrm{C}$, g. $22177149 \mathrm{~T}>\mathrm{C}$ SNPs were significantly associated with EN $(P<0.05)$. Birds with the TC genotype at these SNPs had significantly higher 
TABLE 2: Summary of variations in the chicken INHA gene.

\begin{tabular}{llccc}
\hline Primer pairs no. & Variations & Chr. position & Gene region & Function \\
\hline P1 & g. $22176805 \mathrm{C}>\mathrm{T}$ & 22176805 & Promoter region & - \\
P1 & g. $22176870 \mathrm{~T}>\mathrm{C}$ & 22176870 & Exon 1 & Synonymous \\
P2 & g. $22177100 \mathrm{~T}>\mathrm{C}$ & 22177100 & Exon 1 & Synonymous \\
P2 & g. $22177149 \mathrm{~T}>\mathrm{C}$ & 22177149 & Exon 1 & Synonymous \\
P3 & g. $22177991 \mathrm{~A}>\mathrm{G}$ & 22177991 & Exon 2 & Missense \\
P3 & g. $22178249 \mathrm{G}>\mathrm{C}$ & 22178249 & Exon 2 & Missense \\
P4 & g. $22178414 \mathrm{G}>\mathrm{A}$ & 22178414 & Exon 2 & Missense \\
P4 & g. $22178618 \mathrm{~T}>\mathrm{C}$ & 22178618 & 3' UTR & - \\
P5 & g. $22178681 \mathrm{~A}>\mathrm{T}$ & 22178681 & 3' UTR & 3' UTR \\
P5 & g. $22178728 \mathrm{C}>\mathrm{T}$ & 22178728 & 3' UTR & - \\
P5 & g. $22178835 \mathrm{~A}>\mathrm{G}$ & 22178835 & 3' UTR \\
P5 & g. $22178975 \mathrm{G}>\mathrm{A}$ & 22178975 & & - \\
\hline
\end{tabular}

UTR: Untranslated region. $\mathrm{N}=260$.

TABLE 3: SNPs in 3' UTR of INHA gene disturbed or created the binding sites of miRNAs.

\begin{tabular}{|c|c|c|c|}
\hline Variations & Disturbed miRNAs & Created miRNAs & Binding area \\
\hline \multirow{2}{*}{ g. $22178618 \mathrm{~T}>\mathrm{C}$} & miR-128-3p & \multirow{2}{*}{-} & $22178613-22178619$ \\
\hline & miR-6630-3p & & $22178616-22178621$ \\
\hline \multirow{3}{*}{ g. $22178728 \mathrm{C}>\mathrm{T}$} & \multirow{3}{*}{-} & miR-125b-5p & $22178727-22178733$ \\
\hline & & miR-34b-5p & $22178723-22178728$ \\
\hline & & miR-6673-3p & $22178727-22178732$ \\
\hline \multirow{5}{*}{ g. $22178835 A>G$} & miR-17-3p & \multirow{5}{*}{-} & $22178831-22178837$ \\
\hline & miR-6647-5p & & $22178834-22178839$ \\
\hline & miR-6669-3p & & $22178830-22178835$ \\
\hline & miR-7456-5p & & $22178830-22178837$ \\
\hline & miR-7482-3p & & $22178831-22178837$ \\
\hline \multirow{4}{*}{ g. $22178975 \mathrm{G}>\mathrm{A}$} & miR-181b-1-3p & \multirow{3}{*}{-} & $22178972-22178978$ \\
\hline & miR-6613-3p & & $22178972-22178978$ \\
\hline & miR-6677-5p & & $22178973-22178978$ \\
\hline & - & miR-460b-5p & $22178974-22178980$ \\
\hline
\end{tabular}

ENs than those with the CC genotype. At the INHA exon 2 SNP g. 22177991A $>\mathrm{G}$ was significantly associated with EN $(P=0.025)$, birds with the AG genotype had higher EN values. SNP g. $22178975 \mathrm{G}>\mathrm{A}$ genotypes in INHA gene was significantly associated with EN $(P<0.05)$, with genotype GA had more EN than AA genotype $(P<0.01)$. Conversely, chickens with genotype AA had heavier FEW than those with GA genotype.

3.3. Construction of Haplotypes and Their Associations with Chicken Reproductive Traits. Analysis of LD between SNPs in the INHA gene was shown in Figure 2. Haplotypes were constructed based on the 12 SNPs identified in LH chickens using the Haploview program (Table 7). H1 was the most frequent haplotype at $53.7 \%$. Ten diplotypes were obtained based on these five haplotypes (Table 8 ). However, no significant associations were determined between the reproductive traits in the chicken population and the haplotypes according to regression coefficient analysis.
3.4. Expression of INHA in the Chicken Reproductive System. According to expression analysis, INHA is mainly expressed in the ovary and follicles (F1-F5, SYF, and LWF). During development of chicken follicles, the relative abundance of INHA mRNA initially increased and then decreased, with significantly higher expression in F5 than others $(P<0.05)$. In pre-grade follicles, the INHA mRNA expression increased abruptly in SWF follicle $(P<0.05)$. Expression levels in the F1, F2, and F3 follicles were low and did not significantly differ from each other $(P>0.05)$ (Figure 3(a)).

The protein expression levels of INHA in different chicken period follicles were detected by Western blotting, with $\beta$-actin protein used as a reference. The results showed higher expression of the INHA protein in F5 compared with other follicles $(P<0.01)$ (Figure $3(\mathrm{~b}))$. In the prehierarchical follicles, INHA protein was highly expressed in SYF. These results suggested that INHA is a potential candidate gene for improving chicken reproductive traits. 
TABLE 4: Genotypic and allele frequencies and the genetic information of SNP sites of the chicken INHA gene.

\begin{tabular}{|c|c|c|c|c|c|c|c|}
\hline \multirow{2}{*}{$\begin{array}{l}\text { SNPs } \\
\text { SNP1 }\end{array}$} & \multicolumn{3}{|c|}{ Genotype frequency (\%) } & \multicolumn{2}{|c|}{ Allele frequency (\%) } & \multirow[t]{2}{*}{ PIC } & \multirow[t]{2}{*}{$\mathrm{P}$-value } \\
\hline & $\mathrm{CC}$ & $\mathrm{CT}$ & TT & $\mathrm{C}$ & $\mathrm{T}$ & & \\
\hline $\mathrm{C} 22176805 \mathrm{~T}$ & 31.03 & 61.21 & 7.76 & 61.635 & 38.365 & 0.3611 & $\mathrm{P}=0.0068$ \\
\hline SNP2 & $\mathrm{TT}$ & $\mathrm{TC}$ & $\mathrm{CC}$ & $\mathrm{T}$ & C & & \\
\hline T22176870C & 35.35 & 55.17 & 9.48 & 62.935 & 37.065 & 0.3577 & $\mathrm{P}=0.0821$ \\
\hline SNP3 & $\mathrm{TT}$ & $\mathrm{TC}$ & $\mathrm{CC}$ & $\mathrm{T}$ & $\mathrm{C}$ & & \\
\hline T22177100C & 37.07 & 54.31 & 8.62 & 64.225 & 35.775 & 0.3539 & $\mathrm{P}=0.0835$ \\
\hline SNP4 & $\mathrm{TT}$ & $\mathrm{TC}$ & $\mathrm{CC}$ & $\mathrm{T}$ & C & & \\
\hline T22177149C & 34.49 & 56.03 & 9.48 & 62.505 & 37.495 & 0.3589 & $\mathrm{P}=0.0835$ \\
\hline SNP5 & AA & AG & GG & A & G & & \\
\hline A22177991G & 10.34 & 52.59 & 37.07 & 36.635 & 63.365 & 0.3565 & $\mathrm{P}=0.235$ \\
\hline SNP6 & GG & GC & $\mathrm{CC}$ & G & C & & \\
\hline G22178249C & 13.80 & 55.17 & 31.03 & 41.385 & 58.615 & 0.3675 & $\mathrm{P}=0.2132$ \\
\hline SNP7 & GG & GA & $\mathrm{AA}$ & G & A & & \\
\hline G22178414A & 30.17 & 56.03 & 13.80 & 58.185 & 41.815 & 0.3682 & $\mathrm{P}=0.1611$ \\
\hline SNP8 & $\mathrm{TT}$ & $\mathrm{TC}$ & $\mathrm{CC}$ & $\mathrm{T}$ & C & & \\
\hline T22178618C & 31.03 & 55.17 & 13.80 & 58.615 & 41.385 & 0.3675 & $\mathrm{P}=0.2132$ \\
\hline SNP9 & $\mathrm{AA}$ & $\mathrm{AT}$ & $\mathrm{TT}$ & A & $\mathrm{T}$ & & \\
\hline A22178681T & 31.03 & 55.17 & 13.80 & 58.615 & 41.385 & 0.3675 & $\mathrm{P}=0.2132$ \\
\hline SNP10 & CC & $\mathrm{CT}$ & $\mathrm{TT}$ & C & $\mathrm{T}$ & & \\
\hline $\mathrm{C} 22178728 \mathrm{~T}$ & 14.66 & 55.17 & 30.17 & 42.245 & 57.755 & 0.3689 & $\mathrm{P}=0.2403$ \\
\hline SNP11 & AA & AG & GG & A & G & & \\
\hline A22178835G & 12.94 & 56.03 & 31.03 & 40.955 & 59.045 & 0.3667 & $\mathrm{P}=0.2132$ \\
\hline SNP12 & GG & GA & AA & G & A & & \\
\hline G22178975A & 19.83 & 57.76 & 22.41 & 48.71 & 51.29 & 0.3748 & $\mathrm{P}=0.1467$ \\
\hline
\end{tabular}

$\mathrm{P}$-value is the result of $\chi^{2}$ test of Hardy-Weinberg equilibrium; $\mathrm{PIC}<0.25$ indicated low polymorphism, $0.25<\mathrm{PIC}<0.50$ indicated intermediate polymorphism, and PIC $>0.50$ indicated high polymorphism.

TABLE 5: Association of INHA polymorphisms with chicken reproductive traits.

\begin{tabular}{|c|c|c|c|c|c|c|}
\hline \multirow{2}{*}{ Polymorphism } & \multicolumn{6}{|c|}{ Traits (P value of significant test) } \\
\hline & AFE(days) & BWFE(g) & FEW $(g)$ & BWTA $(g)$ & EWTA(g) & EN(count) \\
\hline g. $22176805 \mathrm{C}>\mathrm{T}$ & 0.838 & 0.407 & 0.962 & 0.308 & 0.192 & 0.353 \\
\hline g. $22176870 \mathrm{~T}>\mathrm{C}$ & 0.214 & 0.406 & 0.998 & 0.457 & 0.876 & $0.017 *$ \\
\hline g. $22177100 \mathrm{~T}>\mathrm{C}$ & 0.296 & 0.259 & 0.954 & 0.222 & 0.846 & $0.022 *$ \\
\hline g. $22177149 \mathrm{~T}>\mathrm{C}$ & 0.516 & 0.203 & 0.967 & 0.211 & 0.820 & $0.033 *$ \\
\hline g. $22177991 \mathrm{~A}>\mathrm{G}$ & 0.279 & 0.179 & 0.990 & 0.321 & 0.768 & $0.025 *$ \\
\hline g. $22178249 \mathrm{G}>\mathrm{C}$ & 0.569 & 0.240 & 0.812 & 0.504 & 0.384 & 0.150 \\
\hline g. $22178414 \mathrm{G}>\mathrm{A}$ & 0.707 & 0.393 & 0.757 & 0.618 & 0.380 & 0.259 \\
\hline g. $22178618 \mathrm{~T}>\mathrm{C}$ & 0.569 & 0.185 & 0.830 & 0.344 & 0.573 & 0.124 \\
\hline g. $22178681 \mathrm{~A}>\mathrm{T}$ & 0.569 & 0.185 & 0.830 & 0.344 & 0.573 & 0.124 \\
\hline g. $22178728 \mathrm{C}>\mathrm{T}$ & 0.628 & 0.242 & 0.859 & 0.452 & 0.416 & 0.117 \\
\hline g. $22178835 \mathrm{~A}>\mathrm{G}$ & 0.569 & 0.185 & 0.830 & 0.344 & 0.573 & 0.124 \\
\hline g. $22178975 \mathrm{G}>\mathrm{A}$ & 0.282 & 0.126 & 0.106 & 0.133 & 0.117 & $0.018 *$ \\
\hline
\end{tabular}

* $P \leq 0.05$; AFE=age at first egg; BWFE=body weight at first egg; FEW= first egg weight; BWTA=body weight at 300 days of age; EWTA=egg weight at 300 days of age; EN=total number of eggs at 300 days of age.

\section{Discussion}

Inhibins play key roles in folliculogenesis, oocyte maturation, and embryo development [26]. The INHA gene encodes the functional center of inhibin and may exhibit potential for increasing the ovulation rate in poultry. For example, the downregulation of INHA gene expression in cultured goose granulosa cells resulted in significant increases in apoptosis and proliferation indexes, a reduced percentage of cells in the G1 phase, and a correspondingly elevated percentage of cells in the $S$ phase [20]. Moreover, transgenic mice overexpressing the rat INHA gene exhibited a reduced litter size and longer 
TABLE 6: Association analyses between SNPs of chicken INHA gene and EN.

\begin{tabular}{|c|c|c|c|c|}
\hline SNP & & Genotypes & & P-value \\
\hline \multirow{2}{*}{ g. $22176870 \mathrm{~T}>\mathrm{C}$} & TT & TC & $\mathrm{CC}$ & \\
\hline & $111.512 \pm 1.928^{\mathrm{b}}$ & $117.516 \pm 1.544^{\mathrm{a}}$ & $109.000 \pm 3.723^{b}$ & 0.017 \\
\hline \multirow{2}{*}{ g. $22177100 \mathrm{~T}>\mathrm{C}$} & $\mathrm{TT}$ & TC & CC & \\
\hline & $111.927 \pm 1.939^{\mathrm{b}}$ & $117.250 \pm 1.552^{\mathrm{a}}$ & $109.000 \pm 3.744^{\mathrm{b}}$ & 0.022 \\
\hline \multirow{2}{*}{ g. $22177149 \mathrm{~T}>\mathrm{C}$} & $\mathrm{TT}$ & $\mathrm{TC}$ & CC & \\
\hline & $112.070 \pm 1.887^{\mathrm{b}}$ & $117.365 \pm 1.559^{\mathrm{a}}$ & $107.900 \pm 3.913^{\mathrm{b}}$ & 0.033 \\
\hline \multirow{2}{*}{ g. $22177991 \mathrm{~A}>\mathrm{G}$} & $\mathrm{AA}$ & $\mathrm{AG}$ & GG & \\
\hline & $111.083 \pm 3.576^{\mathrm{b}}$ & $117.607 \pm 1.586^{\mathrm{a}}$ & $111.279 \pm 1.889^{b}$ & 0.025 \\
\hline \multirow{2}{*}{ g. $22178975 \mathrm{G}>\mathrm{A}$} & GG & GA & AA & \\
\hline & $108.769 \pm 2.422^{b}$ & $114.130 \pm 2.575^{\mathrm{b}}$ & $117.000 \pm 1.509^{\mathrm{a}}$ & 0.018 \\
\hline
\end{tabular}

Results are expressed as mean \pm standard errors. Values in the table were the total number of eggs at 300 days of age for different genotypes. Different letters indicate significant differences $(P<0.05)$.

TABLE 7: Haplotypes inferred based on the twelve SNPs.

\begin{tabular}{lcccccccccccc}
\hline Haplotype & SNP1 & SNP2 & SNP3 & SNP4 & SNP5 & SNP6 & SNP7 & SNP8 & SNP9 & SNP10 & SNP11 & Frequency \\
\hline H1 & C & T & T & T & G & C & G & T & A & T & G & 0.54 \\
H2 & T & C & C & C & A & G & A & C & T & C & A & 0.33 \\
H3 & C & T & T & T & G & G & A & C & T & C & A & 0.05 \\
H4 & T & T & T & T & G & C & G & T & A & T & G & 0.02 \\
H5 & C & C & C & C & A & G & A & C & T & C & A & 0.02 \\
\hline
\end{tabular}

TABLE 8: Diplotypes of chicken INHA gene.

\begin{tabular}{lcccccccccc}
\hline Diplotypes & $\mathrm{H} 1 \mathrm{H} 1$ & $\mathrm{H} 1 \mathrm{H} 2$ & $\mathrm{H} 1 \mathrm{H} 3$ & $\mathrm{H} 1 \mathrm{H} 4$ & $\mathrm{H} 2 \mathrm{H} 2$ & $\mathrm{H} 2 \mathrm{H} 3$ & $\mathrm{H} 2 \mathrm{H} 4$ & $\mathrm{H} 2 \mathrm{H} 5$ & $\mathrm{H} 3 \mathrm{H} 4$ & $\mathrm{H} 4 \mathrm{H} 4$ \\
\hline Frequency $(\%)$ & 24.14 & 47.41 & 4.3 & 0.86 & 5.17 & 3.45 & 0.86 & 3.45 & 0.86 & 0.86 \\
\hline
\end{tabular}

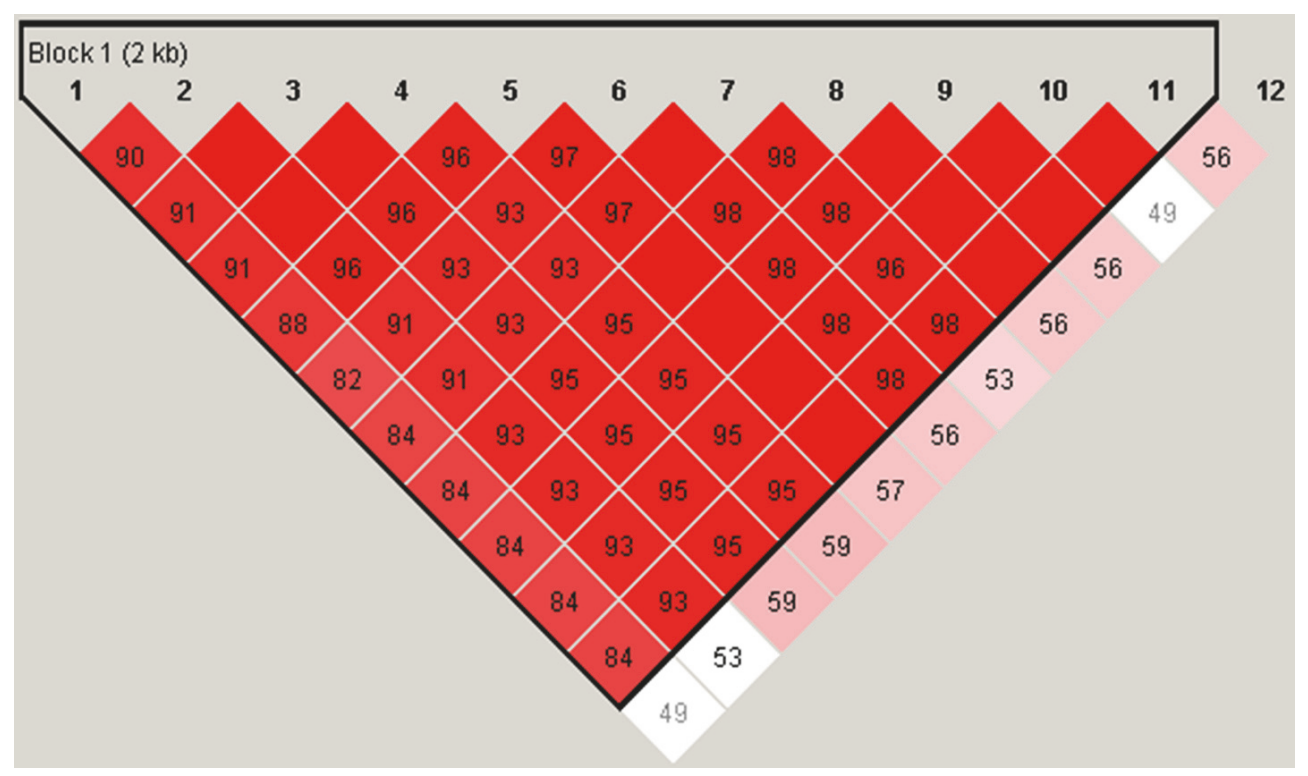

FIgURE 2: LD analyses of SNPs in the INHA gene, the strong LD block is defined as $\mathrm{D}^{\prime} \geq 0.8$. 


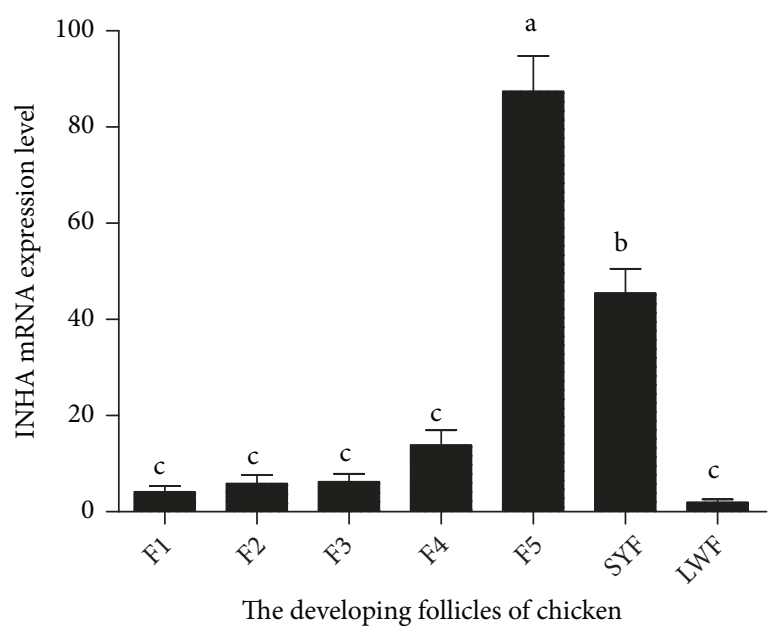

(a)

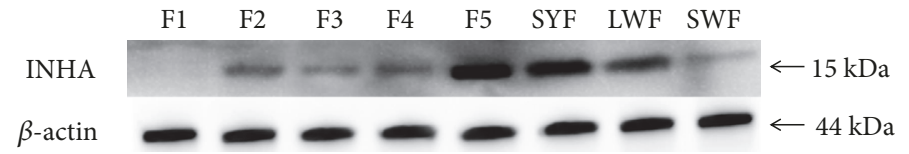

(b)

FIGURE 3: The mRNA and protein expression levels of INHA in chicken reproductive system. (a) The abundance of INHA mRNA. (b) INHA protein detected by Western blotting from the chicken preovulatory follicles and normalized to $\beta$-actin protein content. SWF $=$ small white follicle, $\mathrm{LWF}=$ large white follicle, SYF = small yellow follicle, F5 = the fifth largest preovulatory follicle, F4 = the fourth largest preovulatory follicle, F3 = the third largest preovulatory follicle, F2 = the second largest preovulatory follicle, and F1 = the largest preovulatory follicle. Results are expressed as mean \pm standard deviation $(n=5)$. Least square means with different letters differed significantly $(P<0.05)$.

intervals between pregnancies when compared with control mice [27]. In some studies, polymorphisms in the INHA gene have been found to be significantly associated with follicular cysts in humans [28], pigs [19, 29], and other mammals [30-32]. However, INHA polymorphisms associated with reproductive traits in chicken were previously unknown. The purpose of this experiment was to improve the reproductive performance of LH chickens and provide molecular markers for the selective breeding of laying hens.

Ovulation rate is an important reproductive trait, and the important function of INHA makes it a strong candidate for improving the poultry ovulation rate. We hypothesized that INHA may be a major gene affecting chicken egg production. The AFE, as well as other egg production and egg weight parameters, are important traits used in the breeding of high-quality layers. Therefore, understanding the effects of the INHA gene on these reproductive traits is essential. However, information previously available in the literature regarding the relationships between INHA polymorphisms and reproductive traits was inconclusive.

Recently, several studies in poultry have been identified crucial genes and explored their relationship with phenotypes, such as Liu with 279 Dongxiang blue-shelled chickens [33], Yu with 188 female Muchuan black-boned chickens [34], and EI-Sabrout with 200 Lohmann Brown hens [35]. In this study, 12 SNPs were detected in INHA gene. All SNPs except for SNP1 were in Hardy-Weinberg equilibrium $(P>0.05)$, and their genotype and allele frequencies were above $5 \%$, which indicate that the population is not affected by artificial selection and its sample size is appropriate for association analysis [36].

Five SNPs (g. 22176870T $>$ C, g. $22177100 \mathrm{~T}>\mathrm{C}, \quad$ g. $22177149 \mathrm{~T}>\mathrm{C}$, g. $22177991 \mathrm{~A}>\mathrm{G}$, and g. $22178975 \mathrm{G}>\mathrm{A})$ that were significantly associated with chicken EN. This result is similar to that studied in Boer goats, in which the c.651G $>\mathrm{A}$ mutation in the INHA gene affected the lambing rate [31]. Egg production is an important economic indicator in the poultry industry, and in poultry breeding programs, EN is considered the most valuable indicator of total egg production potential. Our findings therefore confirm the influence of INHA polymorphisms on the female reproductive traits of $\mathrm{LH}$ chickens. We therefore deduce that INHA is an important gene for improving the EN in chickens.

The SNP g. 22177991A > G results in the amino acid substitutions $\mathrm{Val} \longrightarrow \mathrm{Ala}$. $\mathrm{Zi}$ et al. found that sequence variation in INHA was associated with the prolificacy of goat breeds, suggesting that amino acid substitutions in this gene may affect reproductive traits in chicken [37]. While SNP3 results in a synonymous mutation that causes no amino acid change, this mutation was still associated with a reproductive trait. One explanation for this is that this mutation may affect INHA function by altering the stability of the mRNA and its translation efficiency. Therefore, this SNP may be associated with the mRNA expression level and increase in INHA concentration may lead to decreases in FSH concentrations [38].

Zhu et al. analyzed miRNA-related SNPs and found that two SNPs in the 3' UTRs of target genes were predicted to either disturb or create miRNA-target interactions [39]. In the present study, SNP g. 22178618T $>$ C in the 3' UTR of INHA was predicted to disturb miR-128-3p combination. Yu et al. confirmed the suppression of CYP2C9 by the miRNA hsa-miR-128-3p in human liver cells and its association with hepatocellular carcinoma [40], while miR-128-3p was found to suppress hepatocellular carcinoma proliferation [41]. SNP g. $22178728 \mathrm{C}>\mathrm{T}$ was predicted to create bindings sites for two miRNAs miR-125b-5p and miR-34b-5p. miR-125b-5p serves as a novel biomarker for HBV-positive hepatocellular 
carcinoma [42], and miR-34b-5p inhibits the expression of $\mathrm{Bcl}-2$ in ovarian cancer cells [43]. This suggests that miRNArelated SNPs in the 3' UTR of INHA may affect poultry reproductive performance. Further studies are needed to confirm that miRNA-related SNPs regulate mRNA and protein expression levels.

Good laying performance of poultry depends on the growth and development of follicles in the ovary. In poultry, only a few of the large number of follicles mature, with only about $5 \%$ developing into SYF. Improving the laying rate and reproductive performance of native chicken breeds has become an urgent concern for chicken breeding and production. The expression levels and forms of inhibin are closely related to physiological activities such as follicular development, recruitment, and dominance selection. Furthermore, as INHA is the functional center of inhibin, we hypothesis that the expression level of the chicken INHA gene plays a dominant role in follicle development and is related to chicken reproductive traits. Although many studies have shown INHA to be a critical regulator of gonadal function, little is known about its expression in chicken developing follicles and the association between its expression and reproductive traits. In this study, we found that the INHA gene only expressed in the developing follicles. Intriguingly, INHA mRNA expression was the lowest in F1 and highest in F5, consistent with previous results in humans [44]. In the prehierarchical follicles, INHA mRNA expression increased sharply in the SWF. Zi et al. previously found that the mRNA expression levels of INHA affected prolificacy in goats [37]. The development of LWF into SYF is an important process in the recruitment of follicles in poultry [45]. Additionally, the INHA protein expression profile in the follicle was similar to that of its mRNA counterpart with greater expression in F5 and SYF follicles. These results indicate that the expression of INHA is related to follicle development. It can therefore hypothesize that INHA is involved in the regulation of follicle development, playing a critical role in follicle recruitment. Further study is needed to illuminate the specific action mechanism of INHA.

\section{Conclusion}

Generally, 12 SNPs were identified in chicken INHA gene. Five of them were significant associated with egg numbers. Among the exonic SNPs, g. 22177991A>G, g. 22178249G>C, and g. 22178414G $>$ A were missense mutations, which resulted in the amino acid substitutions Val $\longrightarrow$ Ala, Ala $\longrightarrow$ Gly, and Ala $\longrightarrow$ Gly. In addition, INHA highly expressed in F5 and SYF follicles. Therefore, we conclude that INHA is a candidate gene affecting egg production, and it plays a critical role in the recruitment of follicles in chickens. INHA SNPs are possible molecular markers for the genetic selection of layers.

\section{Data Availability}

The data used to support the findings of this study are available from the corresponding author upon request.

\section{Conflicts of Interest}

The authors declared no conflicts of interest.

\section{Authors' Contributions}

Zhifu Cui and Lingbin Liu contributed equally to this work.

\section{Acknowledgments}

The authors gratefully acknowledge Lin Ye for sample collection. This work was financially supported by scientific research fund of Sichuan Provincial education department (15ZA0025), the Thirteenth Five Year Plan for Breeding Program in Sichuan (2016NYZ0050), and the China Agriculture Research System (CARS-41).

\section{References}

[1] C. Welt, Y. Sidis, H. Keutmann, and A. Schneyer, "Activins, inhibins, and follistatins: from endocrinology to signaling. A paradigm for the new millennium," Experimental Biology and Medicine, vol. 227, no. 9, pp. 724-752, 2002.

[2] S. Ying, "Inhibins and activins: chemical properties and biological activity," Experimental Biology and Medicine, vol. 186, no. 3, pp. 253-264, 1987.

[3] T. K. Woodruff and J. P. Mather, "Inhibin, activin and the female reproductive axis," Annual Review of Physiology, vol. 57, no. 1, pp. 219-244, 1995.

[4] P. Knight, "Roles of inhibins, activins, and follistatin in the female reproductive system," Frontiers in Neuroendocrinology, vol. 17, no. 4, pp. 476-509, 1996.

[5] A. L. L. Durlinger, P. Kramer, B. Karels et al., "Control of primordial follicle recruitment by anti-mullerian hormone in the mouse ovary," Endocrinology, vol. 140, no. 12, pp. 5789-5796, 1999.

[6] S. Yang and S. Yu, "The advance on apoptosis regulated by hormones in ovarian follicles," Dongwu Yixue Jinzhan, vol. 23, no. 2, pp. 1-5, 2001.

[7] X. Chen and X. Jiang, "The apoptosis and mechanism of ovary cells," Heilongjiang Journal of Animal Reproduction, vol. 12, pp. 13-18, 2004.

[8] J. Findlay, A. Drummond, K. Britt et al., "The roles of activins, inhibins and estrogen in early committed follicles," Molecular and Cellular Endocrinology, vol. 163, no. 1-2, pp. 81-87, 2000.

[9] P. G. Knight and C. Glister, "Potential local regulatory functions of inhibins, activins and follistatin in the ovary," Reproduction, vol. 121, no. 4, pp. 503-512, 2001.

[10] P. Johnson, C. Brooks, and A. Davis, "Pattern of secretion of immunoreactive inhibin/activin subunits by avian granulosa cells," General and Comparative Endocrinology, vol. 141, no. 3, pp. 233-239, 2005.

[11] D. Tannetta, S. Feist, E. Bleach, N. Groome, L. Evans, and P. Knight, "Effects of active immunization of sheep against an amino terminal peptide of the inhibin alpha $\mathrm{C}$ subunit on intrafollicular levels of activin A, inhibin A and follistatin," Journal of Endocrinology, vol. 157, no. 1, pp. 157-168, 1998.

[12] F. Shi, K. Mochida, O. Suzuki et al., "Development of embryos in superovulated guinea pigs following active immunization against the inhibin $\alpha$-subunit," Endocrine Journal, vol. 47, no. 4, pp. 451-459, 2000. 
[13] T. M. Lovell, P. G. Knight, N. P. Groome, and R. T. Gladwell, "Changes in plasma inhibin A levels during sexual maturation in the female chicken and the effects of active immunization against inhibin $\alpha$-subunit on reproductive hormone profiles and ovarian function," Biology of Reproduction, vol. 64, no. 1, pp. 188-196, 2001.

[14] X. Jiang, L. Yang, G. Liu et al., "Effects of inhibin $\alpha$ (1-32) gene immunization on mouse reproductive traits," Chinese Journal of Veterinary Science, vol. 22, pp. 368-370, 2002.

[15] M. S. Medan, T. Takedom, Y. Aoyagi et al., "The effect of active immunization against inhibin on gonadotropin secretions and follicular dynamics during the estrous cycle in cows," The Journal of Reproduction and Development, vol. 52, no. 1, pp. 107113, 2006.

[16] M. M. Matzuk, M. J. Finegold, J.-G. J. Su, A. J. W. Hsueh, and A. Bradley, "Alpha-inhibin is a tumour-suppressor gene with gonadal specificity in mice," Nature, vol. 360, no. 6402, pp. 313319, 1992.

[17] M. M. Matzuk, M. J. Finegold, J. P. Mather, L. Krummen, $\mathrm{H}$. Lu, and A. Bradley, "Development of cancer cachexialike syndrome and adrenal tumors in inhibin-deficient mice," Proceedings of the National Acadamy of Sciences of the United States of America, vol. 91, no. 19, pp. 8817-8821, 1994.

[18] B. D. Looyenga and G. D. Hammer, "Origin and identity of adrenocortical tumors in inhibin knockout mice: implications for cellular plasticity in the adrenal cortex," Molecular Endocrinology, vol. 20, no. 11, pp. 2848-2863, 2006.

[19] W. Li, L. Sun, S. Chen et al., "Association of inhibin- $\alpha$ gene polymorphisms with follicular cysts in large white sows," Theriogenology, vol. 84, no. 6, pp. 839-845, 2015.

[20] F. Chen, X. Jiang, X. Chen, G. Liu, and J. Ding, "Effects of downregulation of inhibin $\alpha$ gene expression on apoptosis and proliferation of goose granulosa cells," Journal of Genetics and Genomics, vol. 34, no. 12, pp. 1106-1113, 2007.

[21] J. C. Barrett, B. Fry, J. Maller, and M. J. Daly, "Haploview: analysis and visualization of LD and haplotype maps," Bioinformatics, vol. 21, no. 2, pp. 263-265, 2005.

[22] D. Botstein, R. L. White, M. Skolnick, and R. W. Davis, "Construction of a genetic linkage map in man using restriction fragment length polymorphisms," American Journal of Human Genetics, vol. 32, no. 3, pp. 314-331, 1980.

[23] H.-Y. Xu, Y. Wang, Y.-P. Liu, J.-W. Wang, and Q. Zhu, "Polymorphisms and expression of the chicken POU1F1 gene associated with carcass traits," Molecular Biology Reports, vol. 39, no. 8, pp. 8363-8371, 2012.

[24] K. J. Livak and T. D. Schmittgen, "Analysis of relative gene expression data using real-time quantitative PCR and the $2^{-\triangle \Delta C T}$ method," Methods, vol. 25, no. 4, pp. 402-408, 2001.

[25] L. Liu, D. Li, E. R. Gilbert et al., "Effect of monochromatic light on expression of estrogen receptor (ER) and progesterone receptor (PR) in ovarian follicles of Chicken," PLoS ONE, vol. 10, no. 12, Article ID 0144102, 2015.

[26] A. V. Sirotkin, "Cytokines: signalling molecules controlling ovarian functions," The International Journal of Biochemistry \& Cell Biology, vol. 43, no. 6, pp. 857-861, 2011.

[27] B.-N. Cho, M. L. McMullen, L. Pei, C. J. Yates, and K. E. Mayo, "Reproductive deficiencies in transgenic mice expressing the rat inhibin $\alpha$-subunit gene," Endocrinology, vol. 142, no. 11, pp. 4994-5004, 2001.

[28] H. Rah, Y. J. Jeon, J. J. Ko et al., "Association of inhibin $\alpha$ gene promoter polymorphisms with risk of idiopathic primary ovarian insufficiency in Korean women," Maturitas, vol. 77, no. 2, pp. 163-167, 2014.

[29] W. Li, S. Chen, H. Li et al., "A new insertion/deletion fragment polymorphism of inhibin- $\alpha$ gene associated with follicular cysts in Large White sows," Journal of Veterinary Medical Science, vol. 78, no. 3, pp. 473-476, 2016.

[30] S. E. Harris, A. L. Chand, I. M. Winship et al., "INHA promoter polymorphisms are associated with premature ovarian failure," MHR: Basic science of reproductive medicine, vol. 11, no. 11, pp. 779-784, 2005.

[31] W. Wu, G. Hua, L. Yang et al., "Association analysis of the INHA gene with litter size in Boer goats," Small Ruminant Research, vol. 82, no. 2-3, pp. 139-143, 2009.

[32] K. Tang, S. Li, W. Yang et al., "An MspI polymorphism in the inhibin alpha gene and its associations with superovulation traits in Chinese Holstein cows," Molecular Biology Reports, vol. 38, no. 1, pp. 17-21, 2011.

[33] L. Liu, Z. Cui, Q. Xiao et al., "Polymorphisms in the chicken growth differentiation factor 9 gene associated with reproductive traits," BioMed Research International, vol. 2018, Article ID 9345473, 11 pages, 2018.

[34] S. Yu, J. Liao, M. Tang et al., "A functional single nucleotide polymorphism in the tyrosinase gene promoter affects skin color and transcription activity in the black-boned chicken," Poultry Science, vol. 96, no. 11, pp. 4061-4067, 2017.

[35] K. El-Sabrout and S. Aggag, "Association of single nucleotide polymorphism in melanocortin receptor gene with egg production traits in Lohmann Brown chickens," Kafkas Universitesi Veteriner Fakultesi Dergisi, vol. 24, no. 1, pp. 145-148, 2018.

[36] G. Salanti and J. P. A. Ioannidis, "Hardy-Weinberg equilibrium," Encyclopedia of Ecology, vol. 17, no. 1, pp. 1844-1846, 2008.

[37] X.-D. Zi, H.-W. Xu, and Y. Wang, "Variation in sequences and mRNA expression levels of inhibin subunits $\alpha$ (INHA) and $\beta$ A (INHBA) genes between prolific and nonprolific goat breeds," Molecular Reproduction and Development, vol. 79, no. 4, p. 238, 2012.

[38] F. Capon, M. H. Allen, M. Ameen et al., "A synonymous SNP of the corneodesmosin gene leads to increased mRNA stability and demonstrates association with psoriasis across diverse ethnic groups," Human Molecular Genetics, vol. 13, no. 20, pp. 2361-2368, 2004.

[39] Y. Zhu, W. Xue, J. Wang et al., "Identification of common carp (Cyprinus carpio) microRNAs and microRNA-related SNPs," BMC Genomics, vol. 13, no. 1, p. 413, 2012.

[40] D. Yu, B. Green, A. Marrone et al., "Suppression of CYP2C9 by MicroRNA hsa-miR-128-3p in Human Liver Cells and Association with Hepatocellular Carcinoma," Scientific Reports, vol. 5, no. 1, pp. 8534-8534, 2015.

[41] C. Huang, X. Huang, J. Zhu et al., "miR-128-3p suppresses hepatocellular carcinoma proliferation by regulating PIK3R1 and is correlated with the prognosis of HCC patients," Oncology Reports, vol. 33, no. 6, pp. 2889-2898, 2015.

[42] B. G. Giray, G. Emekdas, S. Tezcan et al., "Profiles of serum microRNAs; miR-125b-5p and miR223-3p serve as novel biomarkers for HBV-positive hepatocellular carcinoma," Molecular Biology Reports, vol. 41, no. 7, pp. 4513-4519, 2014.

[43] Y. L. Xie, Y. J. Yang, C. Tang et al., "Estrogen combined with progesterone decreases cell proliferation and inhibits the expression of Bcl-2 via microRNA let-7a and miR-34b in ovarian cancer cells," Clinical and Translational Oncology, vol. 16, no. 10, pp. 898-905, 2014. 
[44] C. K. Welt and A. L. Schneyer, "Differential regulation of inhibin $\mathrm{B}$ and inhibin A by follicle-stimulating hormone and local growth factors in human granulosa cells from small antral follicles," The Journal of Clinical Endocrinology \& Metabolism, vol. 86, no. 1, pp. 330-336, 2001.

[45] M. Safi, N. Buys, O. M. Onagbesan, B. Vleugels, and E. Decuypere, "Quantification of inhibin/activin $\alpha$ and $\beta(\mathrm{A})$ subunit messenger ribonucleic acid by competitive reverse transcription-polymerase chain reaction in chicken granulosa cells during follicular development," Biology of Reproduction, vol. 59, no. 5, pp. 1047-1054, 1998. 


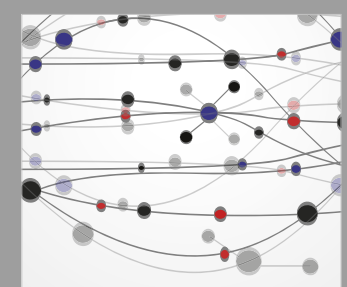

The Scientific World Journal
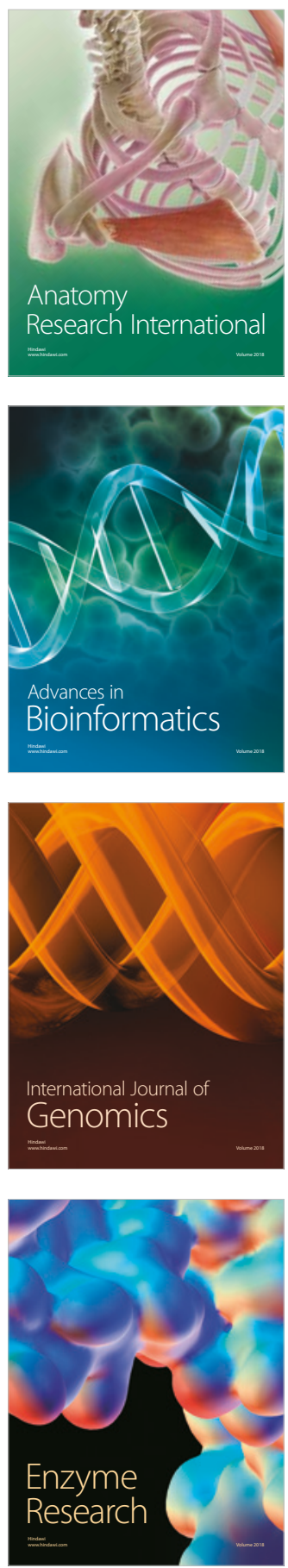
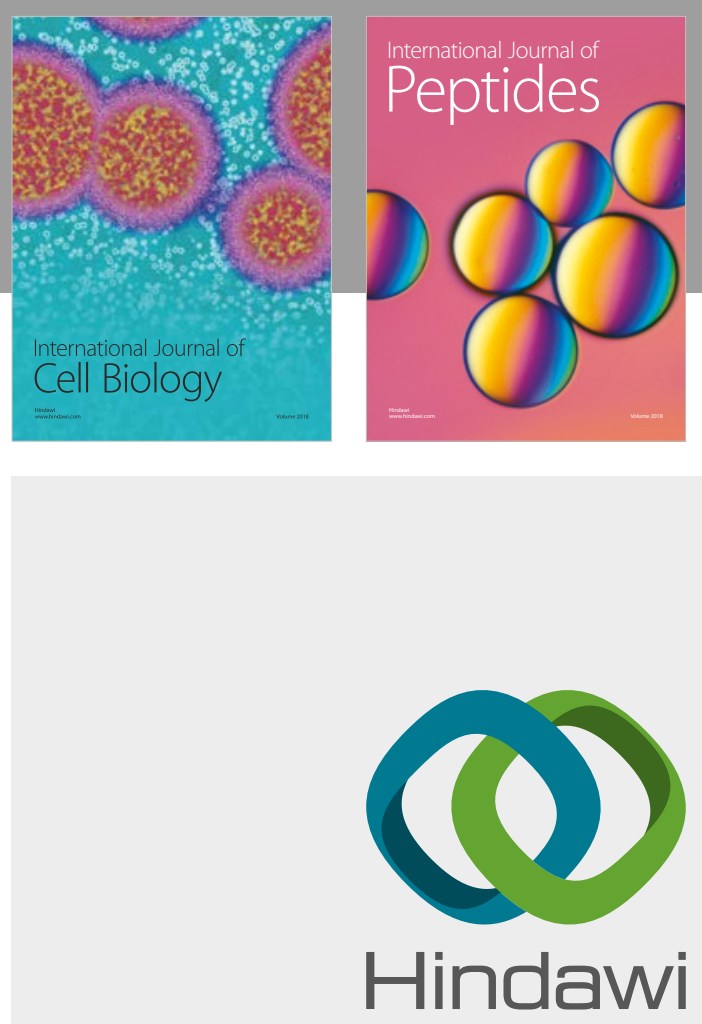

Submit your manuscripts at

www.hindawi.com
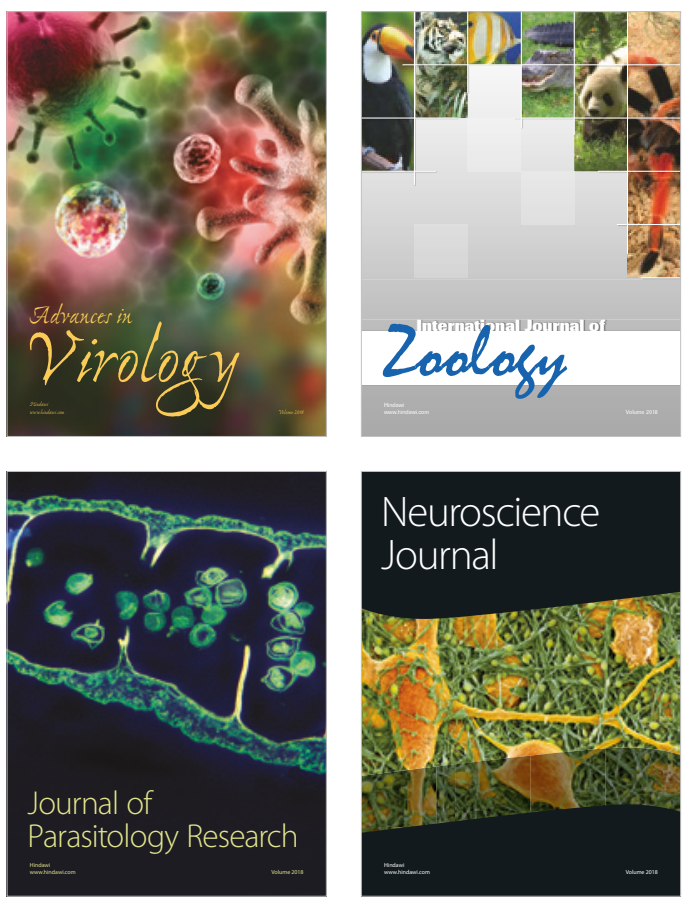
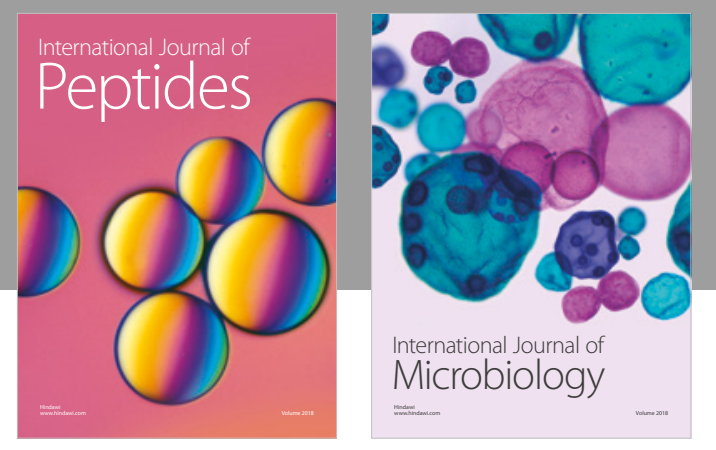

nternational Journal of Microbiology
Journal of
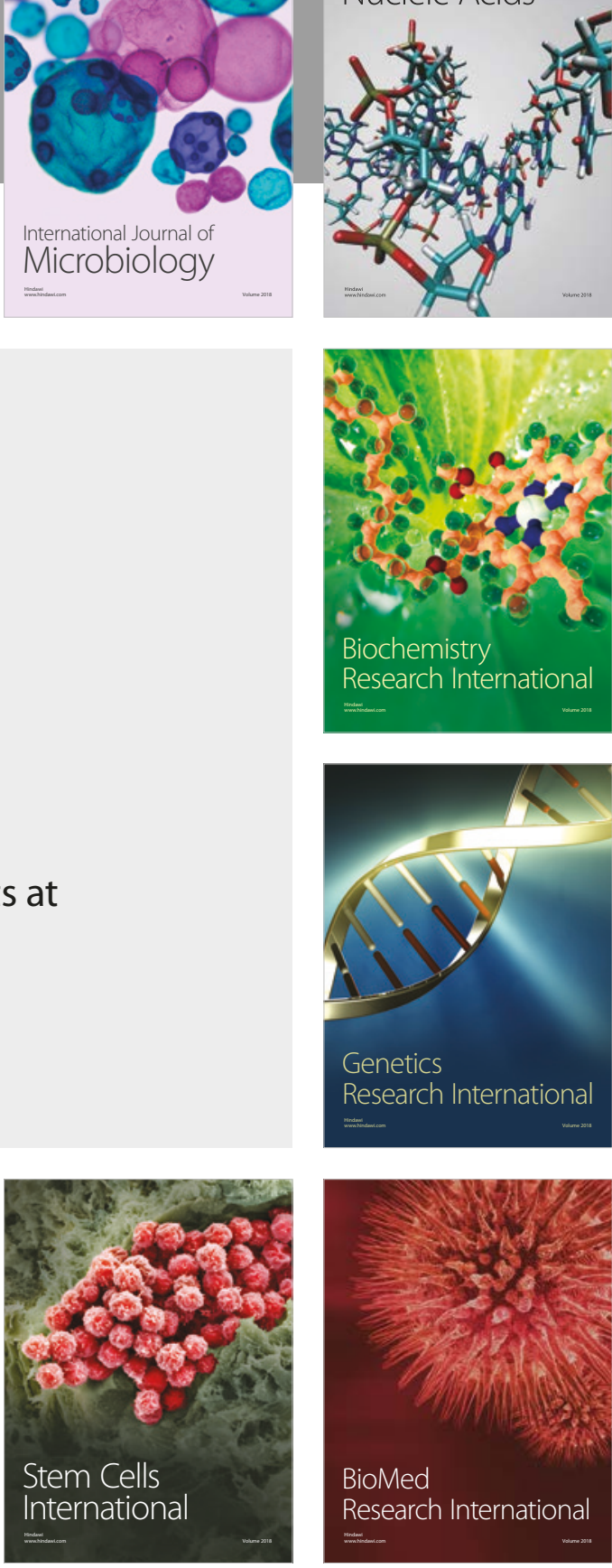
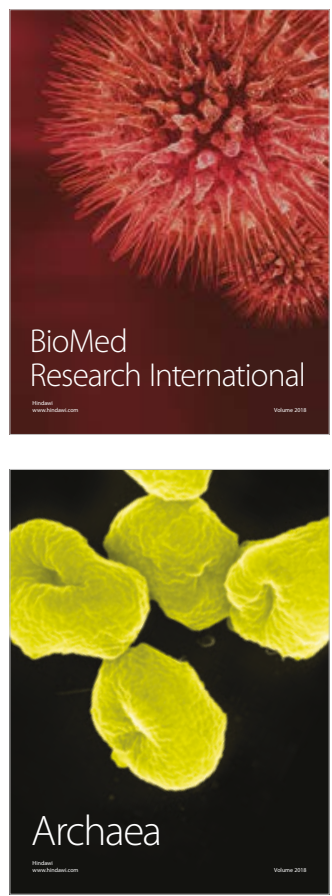